\title{
Prevention and Reduction of Odour Nuisance in Waste Management in the Context of the Current Legal and Technological Solutions
}

\author{
Marcin Pawnuk' ${ }^{1}$ Agnieszka Grzelka' ${ }^{1}$ Urszula Miller' ${ }^{1}$ Izabela Sówka ${ }^{1 *}$ \\ 1 Wrocław University of Science and Technology, Faculty of Environmental Engineering, Department of \\ Environment Protection Engineering, Wyb. Wyspiańskiego 27, 50-370 Wrocław, Poland \\ * Corresponding author's e-mail: izabela.sowka@pwr.edu.pl
}

\begin{abstract}
Excessive odour emission, and thus the potential effect of unpleasant odours in the form of odour nuisance for residents, is a problem that affects many different waste management facilities. In order to prevent and reduce odour emissions, it is necessary to define specific clear and strict legal solutions and to use appropriate technologies. The Polish law indicates that waste management should not cause a nuisance. Despite this fact, legal solutions at the national level are not clear and precise. They are limited to only a few entries. At the European level, BREF Documents have been developed, which are a set of solutions that can be successfully used to counteract odour emissions. On their basis, BAT Conclusions were created, constituting a set of the best available techniques applicable, among others, to reduce the odour emissions from the waste management facilities. By way of implementation into Polish law, they constitute valid standards for prevention and control of odour emissions. The paper presents several solutions demonstrated in the above-mentioned documents aimed at preventing and reducing odour emissions. Various activities, not only those at the technological level but also related to management and planning, in combination with the best available technology allow for effective prevention and control of odour emissions, which could improve the state of environment around the waste management facilities and the quality of human life.
\end{abstract}

Keywords: odours, odour nuisance, waste management, Best Available Techniques, BAT, odour prevention technologies, legal conditions.

\section{INTRODUCTION}

One of the most important documents in Poland regulating the legal issues related to, inter alia, the generation of waste and its management is The Act of 14 December 2012 on waste (Journal of Laws of 2020, item 797) [Act on waste, 2012]. It says that waste management should be carried out in such a way that ensures adequate protection of human life and health as well as protection of the environment with an indication that it must not cause odour nuisance. Despite the clearly defined goals to be followed by the generally understood waste management, many facilities that process the municipal waste face the problem of excessive odour emission, which in turn may be the cause of odour nuisance. Waste management and related activities such as waste collection and transport, transshipment and storage, waste treatment, including composting and fermentation, segregation processes, temporal storage, landfilling, and thermal treatment of waste in waste incineration plants, could be a potential source of odour emissions [Sówka et al. 2017a, Sówka et al. 2018, Cheng et al. 2020]. The biodegradable waste contained in the municipal waste stream is mainly responsible for the emission of odours from the abovementioned sources [Kwarciak-Kozłowska and Bańka 2014], which, according to the aforementioned law, means that waste undergoes aerobic or anaerobic digestion with the participation of microorganisms. In addition to the technological conditions related to the waste treatment processes, which may contribute to increased odour emissions (e.g. waste fermentation in biogas plants) [Wiśniewska 2020], location is another important factor. Waste management plants are often located near large clusters of 
residential areas. Excessive odour emission from waste management plants could cause odour nuisance, for the residents in vicinity, which in turn translates into numerous complaints and protests.

One of the most important steps in preventing excessive odour emission and thus counteracting odour nuisance is proper regulation of the legal issues related to the operation of waste management facilities, which could be a potential source of odour emissions.

The purpose of this work was to analyze and characterise the current legal conditions and technological solutions aimed at reducing odour emissions applicable in Poland concerning waste management facilities.

\section{LEGAL CONDITIONS RELATED TO ODOUR EMISSION IN WASTE MANAGEMENT IN POLAND}

There are no specific legal regulations in Polish legislation relating directly to the odour emissions from waste management facilities. There are only a few references regarding the regulation of the aspects related to odour emissions. The Act of 14 December 2012 on waste (Journal of Laws of 2020, item 797) in Chapter 1 , Section II of that Act defines that waste management should be carried out in such a way that it does not cause a nuisance by noise or odours [Act on waste 2012]. The Act of 27 April 2001 Environmental Protection Law (Journal of Laws 2001 No. 62 item 627) provides for the possibility of introducing regulations in the absence of the emission standards and the absence of the permissible levels of a given substance in the air. According to this Act, it is, therefore, possible to introduce, by way of regulation, specific reference values for odorants in the air, methods for assessing air quality, the frequency of exceedances, or periods of averaging measurements of odorants [Environmental Protection Law 2001]. However, these issues remain unregulated. Another document in the Polish legislation that contains direct references to reducing and preventing odour emissions is The Regulation of the Minister of the Environment of 30 April 2013 on waste landfills (Journal of Laws 2013 item 523). This ordinance contains a provision stating that landfills should be surrounded by a green belt a minimum width of 10 meters to minimise the inconvenience associated with the operation of the landfill, including odour emissions [Regulation of the Minister of the Environment 2013]. In 2009, The Draft Law on the prevention of odour nuisance (February 27, 2009) [Polish Ministry of Environment 2009] was presented. This document sets out the rules of conduct in the event of persistent odour nuisance caused by the activities of a given business entity. It also specified the methods for assessing the air odour quality, including, for example, the use of the field measurement method or the use of odour dispersion modelling. It also defined the comparative levels of odours concentration in the air for calculation methods. In the Draft Law, $1 \mathrm{ou} / \mathrm{m}^{3}$ was adopted as the comparative level of odour concentration in the air and the permissible frequency of exceeding the comparative value were determined. The frequency of exceedances according to the project was in the range from 8 to $15 \%$ by $31 / 12 / 2012$ and from 3 to $8 \%$ from the day of 01/01/2013 depending on the type of land development [Polish Ministry of Environment 2009]. This draft was not reflected in the form of a fullfledged Act.

In Poland, despite the lack of specific regulations at the national level, the regulations at the European level also apply due to membership in the European Union. In 2018, Best Available Techniques (BAT) Reference Document for Waste treatment, so-called BREF Document, [Pinnasseau et al. 2018] was presented to the Members of the European Union together with an Annex in the form of an Implementing Decision of the European Union Commission establishing best available techniques (BAT) conclusions for waste treatment [EU Commission 2018]. These documents have been implemented in the content of The Act of 27 April 2001 Environmental Protection Law (Journal of Laws 2001 No. 62 item 627) [Environmental Protection Law 2001] and are valid standards for waste management plants, including, among others, the plants conducting aerobic and anaerobic processing of waste, or mechanical-biological waste treatment processes. The included provisions included, among others, several solutions related to the prevention of odour emissions.

The first of these documents [Pinnasseau et al. 2018] is the effect of the exchange of information between the members of the European Union, interested industries, non-governmental organisations working for environmental protection and the European Commission in the field of 
commonly used techniques, current emission levels and technologies considered to be the best in the waste management sector.

The second mentioned European document, which is reflected in the Polish law and contains the information on the actions taken to reduce the emission of unpleasant odours is The European Union Commission Implementing Decision establishing conclusions on best available techniques (BAT) for waste treatment [EU Commission 2018]. This document was created based on BREF Documents for waste treatment and summarises the best available techniques concerning the waste treatment and contains a detailed description of those techniques. Importantly, BAT conclusions are not prescriptive and allow for the use of other techniques outside those indicated in this document. The use of other techniques should, however, bring the same level of actions towards environmental protection as the techniques indicated in it. BAT conclusions do not cover only the description of techniques within the meaning of technologies that can be used to e.g. reduce the emission of unpleasant odours from facilities dealing with the processing and treatment of waste. They also describe a series of activities not necessarily related to the technological aspects that can be taken to achieve the best overall environmental performance by those facilities [EU Commission 2018]. BAT 1 indicates that to do this, it is necessary to take the actions aimed at implementing and adhering to the environmental management system, which includes both management involvement, the definition of an environmental policy that will ensure the improvement of the environmental performance of installations, determination of appropriate procedures and their implementation, checking efficiency and taking corrective actions, reviews of the environmental management system, taking into account the environmental effects associated with the decommissioning of the installation. BAT 2 indicates several activities aimed at improving the overall environmental performance, it distinguishes, inter alia, the development and implementation of waste characterisation procedures and pre-collection procedures, development and implementation of collection procedures, development and implementation of a tracking system and inventory, development and implementation of a waste quality management system for processing, ensuring waste segregation, ensuring waste compliance before mixing or mixing waste, sorting of supplied solid waste. BAT 10 directly indicates the need for periodic monitoring of odour emissions using EN or ISO and other standards when the EN standards are not available. An example of a standard that can be successfully used in Poland is $P N-E N$ 13725: 2007: Air quality - Determination of odour concentration by dynamic olfactometry. One of the tools indicated by BAT Conclusions in BAT 12 regarding the prevention or reduction of odour emissions are the so-called odour management plans that should include elements such as protocols containing actions and timelines, odour monitoring protocols based on BAT 10, response protocols to the identified odour incidents, and programs to prevent and reduce the odour episodes. Odour management plans should be implemented at the facilities where potential odour emissions and associated potential annoyance are suspected. BAT 13 and 14 indicate several actions aimed towards prevention or reduction of odour emissions. These include the activities related to minimising waste storage time, the use of chemical waste treatment, optimisation of aerobic waste treatment, minimising the number of possible diffuse sources, selection and use of equipment with a high level of integrity, preventing corrosion, limiting the dispersion, collecting and processing diffuse emissions through the use enclosed devices or buildings, maintaining proper pressure in them, directing emissions to emission reduction systems. BAT conclusions specify the recommendations regarding specific waste treatment methods, such as aerobic waste treatment, anaerobic waste treatment, and MBT processes. Table 1 summarises the recommended actions and techniques for the chosen waste treatment processes.

The BAT conclusions [EU Commission 2018] also contain detailed descriptions of the techniques that can be used to reduce and prevent odour emissions. These include, but are not limited to, absorption processes, the use of biological filters, condensation and cryogenic condensation, thermal oxidation, wet scrubbing, the use of leak detection systems and leak elimination programs, or VOC measurements. A detailed description of the techniques used successfully to reduce the emissions from waste management is presented in the next chapter of this work. 
In addition, in Poland, the so-called The Codex on preventing of odour nuisance [Polish Ministry of Environment 2016] was developed. It describes several technological solutions and actions in the form of recommendations that can contribute, like the BREF and
BAT Documents mentioned above, to the prevention and reduction of odour emissions, also in the area of waste management (Table 2).

It should be noted that this document also referred to the EU regulations regarding Best Available Techniques that were in force in time

Table 1. List of odour emission reduction techniques for selected waste treatment processes, (based on [EU Commission 2018])

\begin{tabular}{|c|c|c|c|}
\hline $\begin{array}{c}\text { Type of waste } \\
\text { treatment }\end{array}$ & Recommended actions & $\begin{array}{l}\text { Recommended } \\
\text { techniques to reduce } \\
\text { emissions to air } \\
\text { (including odours) }\end{array}$ & $\begin{array}{l}\text { Based on } \\
\text { the BAT } \\
\text { conclusion }\end{array}$ \\
\hline $\begin{array}{l}\text { Biological } \\
\text { waste } \\
\text { treatment }\end{array}$ & - selection of waste supplied for processing (according to BAT 2) & $\begin{array}{ll}\text { - } & \text { absorption } \\
\text { - } & \text { fiofiltration } \\
\text { - } & \text { thermal oxidation } \\
\text { - } & \text { wet scrubbing }\end{array}$ & $\begin{array}{l}\text { BAT } 33 \\
\text { BAT } 34\end{array}$ \\
\hline $\begin{array}{l}\text { Aerobic waste } \\
\text { treatment }\end{array}$ & $\begin{array}{l}\text { monitoring and control of key waste parameters and processes, } \\
\text { taking into account the characteristics of the input waste (C / N } \\
\text { ratio, particle size), temperature and humidity of windrows, pa- } \\
\text { rameters related to aeration of windrows, dimensions of windrows } \\
\text { also applies to the general BAT conclusions regarding biological } \\
\text { waste treatment }\end{array}$ & $\begin{array}{l}\text { use of coverings } \\
\text { made of semi-per- } \\
\text { meable membranes } \\
\text { adaptation of activi- } \\
\text { ties to meteorological } \\
\text { conditions }\end{array}$ & $\begin{array}{l}\text { BAT } 36 \\
\text { BAT } 37\end{array}$ \\
\hline $\begin{array}{l}\text { Anaerobic } \\
\text { waste } \\
\text { treatment }\end{array}$ & $\begin{array}{l}\text { monitoring and control of key waste and process parameters } \\
\text { through the implementation of manual or automatic monitoring } \\
\text { aimed at ensuring access to the digestion chamber, limiting op- } \\
\text { erational difficulties, such as foaming, which may lead to odour } \\
\text { emissions, ensuring an appropriate failure warning system, sug- } \\
\text { gested monitored parameters is the pH, alkalinity, fermentation } \\
\text { chamber operating temperature, size of loads fed to the fermen- } \\
\text { tation chamber, concentration of volatile fatty acids and ammo- } \\
\text { nia in the chamber and digestate, biogas quantity, composition } \\
\text { and pressure, liquid and foam levels in the chamber } \\
\text { applies to the overall BAT conclusions regarding biological } \\
\text { waste treatment }\end{array}$ & - & BAT 38 \\
\hline $\begin{array}{l}\text { Mechanical- } \\
\text { biological waste } \\
\text { treatment }\end{array}$ & $\begin{array}{l}\text { - also applies to the general BAT conclusions regarding biological } \\
\text { waste treatment } \\
\text { BAT conclusions regarding anaerobic waste treatment and an- } \\
\text { aerobic waste treatment, where applicable, apply to mechanical- } \\
\text { biological waste treatment }\end{array}$ & $\begin{array}{l}\text { - segregation of the } \\
\text { waste gas streams } \\
\text { recirculation of waste } \\
\text { gas }\end{array}$ & BAT 39 \\
\hline
\end{tabular}

Table 2. Proposed solutions to minimise odour emission in the waste management area included in The Codex on preventing of odour nuisance [Polish Ministry of Environment 2016]

\begin{tabular}{|l|l|}
\hline \multicolumn{1}{|c|}{ Odour emission source } & \multicolumn{1}{c|}{ Proposed actions to prevent or minimize odour emissions } \\
\hline Landfills & $\begin{array}{l}\text { Proper location, construction, and shaping of the object, its proper operation, } \\
\text { proper closure and reclamation, proper management of leachate and biogas, } \\
\text { observance of technological regimes, masking of odours, planting of plants. }\end{array}$ \\
\hline Mechanical-Biological Treatment (MBT) & $\begin{array}{l}\text { Proper location, observance of operational procedures, encapsulation of } \\
\text { technological processes, use of appropriate ventilation systems, biological } \\
\text { drying of materials, intake of process gases, use of vacuum aeration, use } \\
\text { of biological additives, use of biogas injection in fermentation chambers, } \\
\text { covering piles during composting and isolating them, masking of odour. }\end{array}$ \\
\hline Composting of waste & $\begin{array}{l}\text { Proper location, observance of operational procedures, encapsulation } \\
\text { of technological processes, use of appropriate ventilation systems, } \\
\text { use of biofiltration, intake of process gases, use of vacuum aeration, } \\
\text { use of biological additives, covering of piles during composting } \\
\text { and their isolation, masking of smell, planting of plants. }\end{array}$ \\
\hline Thermal waste treatment & $\begin{array}{l}\text { Observance of operating procedures, encapsulation of facilities and roofing of } \\
\text { warehouses for waste, the use of appropriate ventilation, the use of vacuum } \\
\text { aeration, the use of appropriate filters and the use of the absorption process. }\end{array}$ \\
\hline
\end{tabular}


of its publication. This Codex indicates the need to take action at various stages of planning, implementation, and operation of facilities that may contribute to the presence of odour nuisance. It indicates, for example, the need for appropriate spatial management, landscaping, and the use of buffer zones.

\section{TECHNOLOGICAL SOLUTIONS IN PREVENTING OF ODOUR EMISSIONS IN ACCORDANCE WITH THE EXISTING REGULATIONS}

In accordance with BREF recommendations for waste treatment, in the event that a new or

Table 3. Advantages, disadvantages, requirements and effectiveness of selected deodorisation methods [Polish Ministry of Environment, 2016, Pinasseau et al. 2018]

\begin{tabular}{|c|c|c|c|c|}
\hline \multicolumn{2}{|c|}{ Requirements to apply } & Advantages & Disadvantages & $\begin{array}{c}\text { Deodorization } \\
\text { efficiency, }\end{array}$ \\
\hline $\begin{array}{l}\text { 을 } \\
\text { 은 } \\
\frac{0}{0} \\
\frac{0}{2}\end{array}$ & $\begin{array}{l}\text { Gas flow velocity } \\
<18 \mathrm{~m} / \mathrm{min} \\
\text { The minimum } \\
\text { thickness of the } \\
\text { AC layer - } 13 \mathrm{~mm} \\
\text { Working time } \\
\text { - } 4-5 \text { years }\end{array}$ & $\begin{array}{l}\text { High deodorization efficiency } \\
\text { The used adsorbent can be } \\
\text { regenerated } \\
\text { Possibility of using } \\
\text { replaceable cartridges } \\
\text { (for small installations) } \\
\text { Relatively low cost compared } \\
\text { to other techniques }\end{array}$ & $\begin{array}{l}\text { High temperature and high humidity may cause } \\
\text { puncture of the bed } \\
\text { High levels of dust can block the bed } \\
\text { Fast sorbent saturation at high odorant } \\
\text { concentrations } \\
\text { Decrease of purification efficiency as the bed } \\
\text { saturation increases } \\
\text { Non-regenerated sorbent is waste } \\
\text { The gas must be pre-cleaned before being } \\
\text { directed to the AC filter }\end{array}$ & $70-99$ \\
\hline 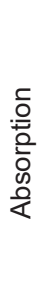 & $\begin{array}{l}\text { A large volume of air } \\
\text { Small pressure drop } \\
\text { The need to ensure } \\
\text { low or medium } \\
\text { odour concentration } \\
\text { The use of reagents } \\
\text { to increase the } \\
\text { effectiveness of } \\
\text { the absorber }\end{array}$ & $\begin{array}{l}\text { Possibility of purifying } \\
\text { large air streams } \\
\text { High cldeodorization } \\
\text { efficiency }\end{array}$ & $\begin{array}{l}\text { In the case of high pollutants concentration, } \\
\text { dilution with clean air is required } \\
\text { For insoluble compounds, chemical reagents } \\
\text { are required } \\
\text { Multi-stage absorption required for } \\
\text { the purification of gases containing } \\
\text { acidic or alkaline compounds } \\
\text { The use of chemical reagents leads to corrosion } \\
\text { and overgrowth of apparatus }\end{array}$ & $60-85$ \\
\hline 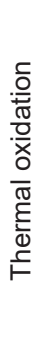 & $\begin{array}{l}\text { Temperature } \\
650-800{ }^{\circ} \mathrm{C} \\
\text { High odorant } \\
\text { concentration } \\
\text { required } \\
\text { Continuous } \\
\text { measurement of } \\
\mathrm{CO}_{2}, \mathrm{O}_{2}, \mathrm{CO} \text { and } \\
\mathrm{NO}_{x} \text { concentration } \\
\text { in waste gases }\end{array}$ & $\begin{array}{l}\text { Possible heat recovery and } \\
\text { secondary heat recovery (hot } \\
\text { water) } \\
\text { Can be used even with very } \\
\text { high odorants concentration }\end{array}$ & $\begin{array}{l}\text { Very high costs } \\
\text { There may be a need for preliminary gas } \\
\text { preparation, including removal of steam from } \\
\text { wet gas and removal of solid or liquid impurities } \\
\text { Burners overgrowing } \\
\text { Formation of soot and secondary odorants } \\
\text { in the event of non-compliance with process } \\
\text { parameters } \\
\text { The need to use dust collectors for dusty gases }\end{array}$ & $98-99,9$ \\
\hline 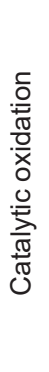 & $\begin{array}{l}\text { The need for } \\
\text { a catalyst } \\
\text { Temperature from } \\
350 \text { to } 400^{\circ} \mathrm{C} \\
\text { The need for a } \\
\text { heat exchanger } \\
\text { High odorant } \\
\text { concentration } \\
\text { The need to remove } \\
\text { solid particles from } \\
\text { purified gases }\end{array}$ & $\begin{array}{l}\text { Can be used even at very } \\
\text { high odorant concentrations } \\
\text { High deodorization efficiency } \\
\text { Possible heat recovery } \\
\text { Accurate knowledge of the } \\
\text { composition and amount of } \\
\text { the substance is not required } \\
\text { Gases may be lightly dusty } \\
\text { and moist } \\
\text { Hot gas purification possible } \\
\text { Low operating costs }\end{array}$ & $\begin{array}{l}\text { Limited stream of purified air; } \\
\text { A sensitive catalyst; } \\
\mathrm{SO}_{2} \text { and } \mathrm{HCl} \text { production } \\
\text { The need for additional purification } \\
\text { Catalyst bed erosion } \\
\text { Not suitable for the purification of gases } \\
\text { containing chlorine and fluorine compounds } \\
\text { Dust blocks the active surface of the catalysts } \\
\text { The need to ensure a constant concentration of } \\
\text { pollutants } \\
\text { Frequent checks required }\end{array}$ & $80-95$ \\
\hline 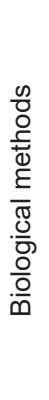 & $\begin{array}{l}\text { Constant mass } \\
\text { stream of odorants } \\
\text { Constant } \\
\text { temperature } \\
\text { Continuous } \\
\text { working time } \\
\text { Working time } \\
3-5 \text { years }\end{array}$ & $\begin{array}{l}\text { Investment and operating } \\
\text { cost lower compared to other } \\
\text { techniques } \\
\text { Almost waste-free technology }\end{array}$ & $\begin{array}{l}\text { A large area for biofilters is required } \\
\text { Not suitable for purifying air with high } \\
\text { concentrations of impurities } \\
\text { The need to maintain a constant temperature, } \\
\mathrm{pH} \text { and humidity } \\
\text { Biofilter operation depends on weather } \\
\text { conditions } \\
\text { Regular irrigation and dosing of nutrients to } \\
\text { biomass required } \\
\text { Slow adaptation of microorganisms to the } \\
\text { concentration of pollutants and gas composition } \\
\text { Can only be used for continuous processes }\end{array}$ & $\begin{array}{c}\text { Biofiltration } \\
70-99 \\
\text { Bioscrubbing } \\
70-80 \\
\text { Biotrickling } \\
\text { filtration } 70-90\end{array}$ \\
\hline
\end{tabular}


Table 4. Area of application of selected deodorisation methods in waste management [based on: Pinnasseau et al. 2018]

\begin{tabular}{|c|c|c|c|c|c|}
\hline \multirow[b]{2}{*}{ Area of application } & \multicolumn{5}{|c|}{ Deodorization method } \\
\hline & $\begin{array}{l}\text { Theramal } \\
\text { oxidation }\end{array}$ & $\begin{array}{l}\text { Biological } \\
\text { methods }\end{array}$ & Condensation & Adsorption & Absorption \\
\hline MBT & + & + & - & + & + \\
\hline Physico-chemical treatment of solid/pasty waste & + & + & - & + & + \\
\hline Treatment of excavated contaminated soil & + & - & - & + & + \\
\hline $\begin{array}{l}\text { Regeneration/recovery of pollution } \\
\text { abatement components/ FGT residues }\end{array}$ & + & - & - & + & - \\
\hline Treatment of water-based liquid waste & + & + & - & + & + \\
\hline Regeneration of spent solvents & + & - & + & + & + \\
\hline Re-refining and other preparations for reuse of waste oils & + & - & + & + & + \\
\hline Treatment of waste containing POPs & + & - & - & + & - \\
\hline Physico-chemical treatment of waste with calorific value & + & - & - & + & - \\
\hline Treatment of waste containing mercury & + & - & + & + & - \\
\hline Aerobic treatment of source-separated biowaste & - & + & - & + & + \\
\hline Anaerobic treatment of bio-waste & - & + & - & + & + \\
\hline Mechanical treatment of waste with calorific value & - & + & - & + & + \\
\hline Treatment of WEEE containing VFCs and/or VHCs & - & + & + & + & \\
\hline Repackaging of hazardous waste & - & - & + & + & + \\
\hline Blending/mixing of waste & - & - & + & + & - \\
\hline Mechanical treatment in shredders of metal waste & - & - & - & + & + \\
\hline
\end{tabular}

an existing installation may contribute to odour nuisance in residential or recreational areas or a workplace, the first step towards preventing the problem of odour emissions is to create an Odour Management Plan (OMP). It should contain, among others, odour monitoring protocol, complaint response protocol and description of planned methods for preventing and reducing odour emissions. The first step to improve the odorous situation in an installation is to prevent the formation of odorants at source. The actions to reduce the odour formation include, first and foremost, minimising waste storage time, in particular under anaerobic conditions, optimising the aerobic processing of waste, as well as using shields and building closed facilities to carry out the processes that may emit odours. In the event that these activities prove to be insufficient, the so-called 'end-of-pipe' methods are recommended [Pinnasseau et al. 2018].

BREF and other literature sources [Estrada et al. 2011, Sówka et al. 2017b, Meeroff et al. 2018, Miller et al. 2018a, Pinnasseau et al. 2018, Gałwa-Widera and Kwarciak-Kozłowska 2019, Gospodarek et al. 2019, Rybarczyk et al. 2019, Turała and Wieczorek 2019, Wysocka et al. 2019] indicate a number of specific technological solutions successfully used in reducing the emission of unpleasant odours from waste management processes. These include such methods as absorption, adsorption, thermal processes, non-thermal oxidation processes and biological methods. Table 3 presents the requirements, advantages and disadvantages of the selected deodorisation methods used in waste management along with the deodorisation efficiency declared for them.

Adsorption is a method in which, as a result of a heterogeneous reaction, gas molecules are retained on the surface of an adsorbent that prefers specific chemical compounds. Granulated activated carbon (GAC), zeolites or macroporous polymer particles are most often used as adsorbent. When the adsorbent is used up, it can be replaced or regenerated. [Pinnasseau et al. 2018, Wysocka et al. 2019]. The absorption method involves mass transfer between the polluted gas and the solvent (water, acid solution or alkaline solution - depending on the removed chemical compound types). The removed component dissolves in the absorbing liquid and, depending on the solvent used, this method may allow the recovery of the absorbed pollutants as a result of reversing the chemical reaction [Schlegelmilch et al. 2005, Pinnasseau et al. 2018]. The condensation method is used to eliminate the VOCs vapours from the waste gas stream, its principle is based on lowering their temperature below the dew point in 
order to condense them [Pinnasseau et al. 2018]. The thermal oxidation method involves the oxidation of odorants found in the waste gas stream by heating the contaminated gases with the addition of air or oxygen in the combustion chamber. It is used to reduce emissions from almost all sources emitting VOCs; however, this method is only applicable to small gas flows due to high fuel consumption [Schlegelmilch et al. 2005, Pinnasseau et al. 2018, Wysocka et al. 2019]. The most commonly used method in recent years involves the biological deodorisation techniques, including primarily biofiltration. In the case of biofilters, this method involves the slow passage of gas through a humidified, porous bed, where the pollution is first absorbed by water, and then as a result of biodegradation processes, removed by the microorganisms inhabiting the bed [Sówka et al. 2014, Sówka et al. 2017b, Grzelka et al. 2018, Miller et al. 2018b, Pinnasseau et al. 2018]. Table 4 summarises the selected deodorisation methods along with areas of use in waste management [Pinasseau et al., 2018]. The analysis of the application of these techniques in waste management shows that for gases generated as a result of municipal waste treatment, an effective and economical solution is to use the biofiltration method and other biological methods. However, these methods are not suitable for discontinuous processes with varying pollutant streams or very high odorant concentrations in the waste gas. For such processes, it is recommended to use the deodorisation methods based on catalytic combustion, adsorption or absorption processes, as well as deodorisation installations combining several different methods.

\section{CONCLUSIONS}

Despite the legal restrictions stating that waste management activities should not have caused an odour nuisance, many facilities are struggling with this problem. In order to prevent extensive odour emissions and thus possible odour nuisance, appropriate legal regulations are needed, which at the national level are limited, and have not entirely precise nature. Membership in the European Union is associated with the implementation of legal regulations introduced within the EU. Such examples are BREF documents and BAT conclusions, which are documents in force throughout the whole European Union, containing a number of guidelines regarding, inter alia, activities, and technologies aimed at preventing and reducing odour emissions. It should be noted that not every action indicated in the documents mentioned above and not every technique could be used in real cases. However, the introduction of specific standards of action and following the latest technologies can significantly contribute to reducing the emission of odours from the objects related to waste management, and thus to improve the lives of residents living in the immediate vicinity of waste management plants by reducing the potential odour nuisance.

\section{Acknowledgments}

This paper was co-financed within the "Excellent Science" program of the Polish Ministry of Science and Higher Education.

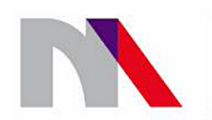

Ministry of Science and Higher Education Republic of Poland

\section{REFERENCES}

1. Commission Implementing Decision (EU) 2018/1147 of 10 August 2018 establishing best available techniques (BAT) conclusions for waste treatment, under Directive 2010/75/EU of the European Parliament and of the Council.

2. Cheng Z., Zhu S., Chen X., Wang L., Lou Z., Feng L. 2020. Variations and environmental impacts of odour emissions along the waste stream. Journal of Hazardous Materials, 384, 120912.

3. Codex on preventing of odour nuisance. Ministry of the Environment, Department of Protection Air and Climate, Warsaw, 2016 (online access: https:// www.gov.pl/web/klimat/uciazliwosc-zapachowa) (in Polish).

4. Estrada J.M., Kraakman N.B., Muñoz R., Lebrero R. 2011. A comparative analysis of odour treatment technologies in wastewater treatment plants. Environmental science \& technology, 45(3), 1100-1106.

5. Gałwa-Widera M., Kwarciak-Kozłowska A. 2019. Reduction of odor nuisance from composting process. Journal of Ecological Engineering, 20(6), 84-89.

6. Gospodarek M., Rybarczyk P., Szulczyński B., Gębicki J. 2019. Comparative evaluation of selected biological methods for the removal of hydrophilic and hydrophobic odorous VOCs from air. Processes, 7(4), 187.

7. Grzelka A., Miller U., Sówka I. 2018. The role of biological methods in the municipal management odor nuisance reduction strategy. Ecological Chemistry Engineering A. 25(1), 51-60. 
8. Kwarciak-Kozłowska A., Bańka B. 2014. Neutralization of odors generated during compostingof biodegradable fraction of municipaland industrial waste by biofiltration. Inżynieria i Ochrona Środowiska, 17(4), 631-645 (in Polish).

9. Meeroff D.E., Roblyer J., Vidovic M. 2018. Investigation of Effective Odor Control Strategies Final Report.

10. Miller U., Grzelka A., Romanik E., Kuriata M. 2018a. Analysis of the application of selected physico-chemical methods in eliminating odor nuisance of municipal facilities. X-th Scientific Conference Air Protection in Theory and Practice, E3S Web of Conferences. 28, 1-8.

11. Miller U., Sówka I., Grzelka A., Pawnuk M. 2018 b. Application of biological deodorization methods in the aspect of sustainable development. The 10th Jubilee Scientific Conference - InfoGlob 2018, SHS Web of Conferences, 57, 1-6.

12. Pinasseau A., Zerger B., Roth J., Canova M., Roudier S. 2018. Best Available Techniques (BAT) Reference Document for Waste treatment Industrial Emissions Directive 2010/75/EU (Integrated Pollution Prevention and Control), Publications Office of the European Union.

13. Polish Ministry of Environment, 2009. Draft: Law on the prevention of odour nuisance, 27.02.2009 (in Polish).

14. Polish standardization committee. 2007. PN-EN 13725: 2007: Air quality - Determination of odour concentration by dynamic olfactometry. Warsaw.

15. Rybarczyk P., Szulczyński B., Gębicki, J., Hupka J. 2019. Treatment of malodorous air in biotrickling filters: A review. Biochemical Engineering Journal, 141, 146-162.

16. Schlegelmilch M., Streese J., Stegmann R. 2005. Odour management and treatment technologies: An overview. Waste Management, 25(9), 928-939.

17. Sówka I., Pawnuk M., Miller U. 2018. Zarządzanie i przeciwdziałanie uciążliwościom zapachowym w gospodarce odpadami - problem odorów. Abrys, Poznań, 74-81 (in Polish).

18. Sówka I., Nych A., Miller U. 2017. Problematyka odorów na składowiskach odpadów. XXVII Konferencja Eksploatacja i rekultywacja składowisk odpadów, Świeradów-Zdrój (in Polish).

19. Sówka I., Miller U., Grzelka A. 2017. The application of dynamic olfactometry in evaluating the efficiency of purifying odorous gases by biofiltration. Environment Protection Engineering, 43(4), 233-242.

20. Sówka I., Miller U., Sobczyński P. 2014. Emission of odors from municipal waste composting process. Przemysł Chemiczny, 93, 795-798 (in Polish).

21. The Act of 14 December 2012 on waste (Journal of Laws of 2020, item 797) (in Polish).

22. The Act of 27 April 2001 Environmental Protection Law (Journal of Laws 2001 No. 62 item 627) (in Polish).

23. The Regulation of the Minister of the Environment of 30 April 2013 on waste landfills (Journal of Laws 2013 item 523) (in Polish).

24. Turała A., Wieczorek A. 2019. Biofiltration of contaminated air - Current status, development trends. Rocznik Ochrona Środowiska, 21, 1001-1020.

25. Wiśniewska M. 2020. Methods of assessing odour emissions from biogas plants processing municipal waste, Journal of Ecological Engineering, 21(1), 140-147.

26. Wysocka I., Gębicki J., Namieśnik J. 2019. Technologies for deodorization of malodorous gases. Environmental Science and Pollution Research, 26, 9409-9434. 